\title{
Daya Gabung Karakteristik Tongkol dari Galur-Galur Inbrida Jagung Manis pada Sistem Budidaya Organik
}

\author{
Combining Abilities of Ear Characteristics on Sweet Corn Inbred Lines \\ Under Organic Cropping System
}

\author{
Mohammad Chozin $^{1 *}$, Sigit Sudjatmiko ${ }^{1}$, Nanik Setyowati ${ }^{1}$, Fahrurrozi $^{1}$, \\ dan Zainal Muktamar ${ }^{1}$
}

Diterima 10 Agustus 2016/Disetujui 08 Februari 2017

\begin{abstract}
The availability of varieties having high-yielding potential and good horticultural characteristics under organic environment is prerequisite for successful organic sweet corn production. Objective of this study was to estimate the general and specific combining abilities of ear characteristics in eight sweet corn inbred lines under organic cropping system. Seeds of 64 genotypes generated from a full diallel crossing scheme of the inbred lines were planted on the experimental plots in a randomized complete block design with 3 replications. Organic managements were practiced during the crop production. Analysis of variance showed highly significant variabilities among the genotypes for ear length, unhusked ear diameter, husked ear diameter, kernel row number, and ear weight. Analyisis of combining ability components revealed that both additive and non-addive gene actions played important roles in the expression of those traits, while reciprocal effect played a minor role in husked ear diameter expression. Based on their general combining abilities, Caps 17A, Caps 17B, and Caps 5 were considered as good combiners for the development high-yielding hybrid varieties under organic cropping system. Caps $2 \times$ Caps 3 was the hybrid with the highest and positive specific combining ability for most of the characters studied.
\end{abstract}

Keywords: general combining ability, hybrid, inbred line, specific combining ability

\begin{abstract}
ABSTRAK
Penyediaan varietas yang berdaya hasil tinggi dengan karakteristik hortikultura baik pada lingkungan organik menjadi prasyarat bagi keberhasilan produksi jagung manis secara organik. Tujuan dari penelitian ini ialah untuk menduga besarnya daya gabung umum dan daya gabung khusus karakteristik tongkol dari delapan galur inbrida jagung manis pada sistem budidaya organik. Benih dari 64 genotipe yang dihasilkan melalui skema persilangan dialel penuh dari galur-galur inbrida tersebut ditanam pada plot-plot percobaan dalam susunan rancangan acak kelompok lengkap dengan 3 ulangan. Pengelolaan secara organik dilakukan selama proses budidaya tanaman. Analisis ragam menunjukkan adanya perbedaan yang sangat nyata antar genotipe untuk panjang tongkol, diameter tongkol berkelobot, diameter tongkol tanpa kelobot, jumlah baris biji per tongkol, dan bobot tongkol. Analisis daya gabung menunjukkan bahwa tindak gen aditif dan non-aditif memiliki peran penting terhadap ekspresi karakter-karakter tersebut, sementara pengaruh resiprokal hanya terlibat pada ekspresi diameter tongkol tanpa kelobot. Berdasarkan nilai daya gabung umumnya, Caps 17A, Caps 17B, dan Caps 5 memiliki potensi sebagai penggabung yang baik untuk pengembangan varietas hibrida berdaya hasil tinggi pada sistem budidaya organik. Caps 2 x Caps 3 merupakan hibrida dengan daya gabung khusus positif tertinggi pada sebagian besar karakter tongkol yang dievaluasi.
\end{abstract}

Kata kunci: daya gabung khusus, daya gabung umum, galur inbrida, hibrida

${ }^{1}$ Jurusan Budidaya Pertanian, Fakultas Pertanian, Universitas Bengkulu.

Jl. W.R. Supratman Kandang Limun Kota Bengkulu 38371 A

Email: mchozin@unib.ac.id (*penulis korespondensi) 


\section{PENDAHULUAN}

Jagung manis (Zea mays saccharata Sturt) merupakan komoditas hortikultura yang dikategorikan sebagai sayuran. Keberadaan jagung manis di Indonesia masih tergolong baru dibanding jenis tanaman sayuran lain, seperti tomat, cabai, atau kubis, sekalipun sama-sama bukan tanaman asli Indonesia. Produksi jagung manis tercatat baru dimulai pada awal tahun 1980-an dengan skala usaha yang relatif kecil sekedar untuk memenuhi kebutuhan hotel dan restoran (Koswara, 1986). Sekalipun data resmi tentang produksi dan luas panen jagung manis secara nasional tidak tersedia, fakta di lapangan menunjukkan bahwa budidaya komoditas tersebut telah tersebar luas di penjuru tanah air dan menjadi usahatani yang menguntungkan (Agustyari et al., 2013; Porotu'o et al., 2013; Susianti dan Rauf, 2013). Permintaan pasar jagung manis dalam negeri yang belum terpenuhi juga memiliki andil besar terhadap animo masyarakat dalam budidaya jagung manis. Tahun 2012, Indonesia harus mengimpor jagung manis sebesar 2674 ton guna memenuhi kebutuhan dalam negeri (Dirjen Hortikultura, 2013).

Meningkatnya popularitas pertanian organik seiring munculnya kesadaran masyarakat untuk mendapatkan bahan pangan yang aman dan sehat serta proses produksi yang lestari telah mendorong berkembangnya budidaya jagung manis secara organik. Berbagai kajian telah dilakukan untuk menunjang keberhasilan sistem pertanian organik untuk produksi jagung manis, mulai dari penyediaan hara (Marvelita et al., 2006; Muhsanati dan Rahayu, 2008; Rahmah et al., 2014), pengendalian organisme pengganggu tanaman (Nurkhasanah, 2012; Sekarsari et al., 2013; Silmi dan Chozin, 2014;Ompusunggu et al., 2015) hingga kultur teknis (Mayadewi dan Nyoman, 2007; Syaiful et al., 2011; Dinariani et al., 2014). Namun, hingga dewasa ini benih yang digunakan untuk budidaya jagung manis secara organik masih sangat tergantung pada varietas-varietas yang dirakit untuk budidaya intensif dengan mengandalkan input tinggi berbasis produk kimia sintetis agar dicapai produktivitas yang tinggi. Varietas-varietas tanaman demikian ini memiliki kelemahan karakter-karakter penting yang berhubungan dengan daya adaptasi pada kondisi organik, seperti kemampuan tumbuh dengan subur pada ketersediaan hara yang terbatas, kemampuan berkompetisi dengan gulma, dan ketahanan terhadap hama dan penyakit (Wolfe, 2003). Karena itu, program pemuliaan jagung manis untuk pengembangan varietas jagung manis yang adaptif kondisi organik serta memiliki karakteristik tongkol baik menjadi keniscayaan yang diperlukan dalam mendukung keberhasilan produksi jagung manis secara organik.

Dalam program pemuliaan penyerbuk silang, seperti jagung manis, evaluasi daya gabung merupakan tahapan penting dalam pemilihan galur-galur inbrida potensial yang akan digunakan sebagai tetua untuk perakitan varietas hibrida maupun varietas sintetis (Poehlman, 2013; Welu, 2016). Daya gabung menjadi indikator kemampuan individu mewariskan sifat keunggulan kepada keturunannya (Acquaah, 2012; Ekowahyuni, 2015). Proses evaluasi idealnya melibatkan semua kemungkinan persilangan dari galurgalur inbrida calon tetua melalui skema persilangan dialel agar informasi bobot serta keunggulan masing-masing galur inbrida dapat diidentifikasi secara menyeluruh. Evaluasi daya gabung melalui persilangan dialel telah banyak dilaporkan untuk berbagai karakter jagung manis (Assunção et al., 2010; Iriany et al., 2011; Solomon et al., 2012; Sadaiah et al., 2013), namun evaluasi umumnya dilakukan dengan sistem budidaya yang melibatkan input agrokimia sintetis. Penelitian ini bertujuan menduga besarnya daya gabung umum dan daya gabung khusus karakteristik tongkol dari delapan galur inbrida melalui pola persilangan dialel pada sistem budidaya organik.

\section{BAHAN DAN METODE}

Materi genetik yang digunakan dalam penelitian ini adalah 64 genotipe jagung manis (8 silang sendiri, 28 hibrida, dan 28 resiprok) keturunan dari persilangan dialel lengkap 8 galur inbrida (Caps 2, Caps 3, Caps 5, Caps 15, Caps 17A, Caps 17B, Caps 22, dan Caps 23). Galur-galur tersebut merupakan generasi 5 silang sendiri $\left(S_{5}\right)$ yang diseleksi berdasarkan penampilan agronomis maupun hortikulturanya pada sistem budidaya organik (Tabel 1). 
Tabel 1. Silsilah galur inbrida yang digunakan dalam penelitian

\begin{tabular}{lll}
\hline No. & Galur & \multicolumn{1}{c}{ Silsilah } \\
\hline 1 & Caps 2 & Bs - 1-2-1-1-2 \\
2 & Caps 3 & Gd -2-2-1-1-2 \\
3 & Caps 5 & Mto C-2-1-1-3 \\
4 & Caps 15 & Sb -1-5-1-4-2 \\
5 & Caps 17A & Sg -2-1-1-2-1 \\
6 & Caps 17B & Sg -2-4-1-3-1 \\
7 & Caps 22 & Bm -3-3-1-3-2 \\
8 & Caps 23 & Si -2-1-1-8-1 \\
\hline
\end{tabular}

Percobaan dilaksanakan di Desa Sukamarga, Kecamatan Curup Timur, Kabupaten Rejang Lebong, Provinsi Bengkulu (600 m di atas permukaan laut). Rancangan acak kelompok lengkap teracak dengan 3 ulangan digunakan untuk mengalokasikan masing-masing genotipe pada petak-petak percobaan berukuran $1 \mathrm{~m}$ x $5 \mathrm{~m}$. Lahan yang digunakan diolah secara manual dengan cangkul hingga siap tanam. Pupuk kandang sapi dengan dosis $5 \mathrm{~kg} \operatorname{petak}^{-1}\left(10 \mathrm{t} \mathrm{ha}^{-1}\right)$ diaplikasikan seminggu sebelum tanam sebagai pupuk organik. Benih ditanam pada tiap petak percobaan dalam bentuk barisan dengan jarak tanam antar baris $70 \mathrm{~cm}$ dan jarak tanam dalam barisan $20 \mathrm{~cm}$. Penanaman dilakukan dengan menempatkan satu benih pada setiap lubang tanam. Penyiangan dilakukan pada 14, 21, dan 28 hari setelah tanam (HST). Pupuk cair organik sebagaimana digunakan oleh Muktamar et al. (2016) dan Fahrurrozi et al. (2016) diaplikasikan sebanyak 4 kali melalui daun sebagai pupuk susulan dengan interval 2 minggu dengan total dosis $700 \mathrm{ml}$ tanaman ${ }^{-1}$. Pengendalian hama tidak dilakukan karena tingkat serangannya tergolong sangat rendah (4\%). Penyakit hawar daun (Helminthosporium turcicum) yang menyerang tanaman jagung dikendalikan dengan penyemprotan suspensi Trichoderma pada tanaman dengan interval 2 minggu hingga tanaman memasuki fase pembungaan. Penjarangan tongkol dilakukan terhadap tongkol yang muncul setelah tongkol pertama memasuki fase pengisian biji, sehingga pada saat panen tiap tanaman hanya memiliki satu tongkol. Panen dilakukan pada 78 hari setelah tanam, yakni ketika tongkol sudah berkembang penuh, rambut tongkol berwarna coklat gelap, dan biji mengeluarkan cairan putih susu jika ditekan.
Data dikumpulkan dari 5 tanaman sampel yang dipilih secara acak dari tiap petak percobaan berdasarkan pengamatan panjang tongkol berkelobot, diameter tongkol berkelobot, diameter tongkol tanpa kelobot, jumlah baris biji per tongkol, jumlah biji per baris, dan bobot tongkol berkelobot. Analisis ragam dilakukan pada tiap karakter tongkol berdasarkan rancangan acak kelompok lengkap. Karakter-karakter yang menunjukkan keragaman antar genotipe selanjutnya digunakan sebagai dasar untuk menduga pengaruh daya gabung, yang meliputi daya gabung umum (DGU), daya gabung khusus (DGK), dan resiprokal dari genotipe-genotipe yang digunakan. Evaluasi daya gabung dilakukan berdasarkan metode I dialel Griffing (1956) dengan prosedur analisis dan uji t untuk DGU maupun DGK berbeda dari nol sebagaimana dikemukakan oleh Singh dan Chaudhary (1985).

\section{HASIL DAN PEMBAHASAN}

\section{Analisis Ragam dan Penampilan Genotipe}

Analisis ragam menunjukkan bahwa 64 genotipe jagung manis yang dievaluasi memiliki perbedaan yang nyata pada panjang tongkol dan sangat nyata pada diameter tongkol berkelobot, diameter tongkol tanpa kelobot, jumlah baris biji per tongkol, dan bobot tongkol berkelobot (Tabel 2). Hasil analisis tersebut menunjukkan adanya faktor genetik yang berperan penting dalam perbedaan ekspresi dari lima karakter tersebut pada galur-galur inbrida dan hibrida yang dihasilkan. Berdasarkan rata-rata penampilan galur (Tabel 3), Caps 17A dan Caps 17B merupakan galur inbrida dengan berpenampilan umum terbaik diantara galur-galur inbrida lainnya, sedangkan hasil persilangan Caps 17A x Caps 5 dan Caps 17A x Caps 15 merupakan hibrida berpenampilan umum terbaik di antara hibrida lainnya. Namun demikian, dalam perakitan varietas hibrida atau sintetis keunggulan penampilan suatu inbrida tidak selalu menjadi indikator bahwa inbrida tersebut dapat berperan sebagai penggabung yang baik. Idealnya, inbrida untuk perakitan varietas hibrida memiliki penampilan yang baik sekaligus memiliki daya gabung yang baik (Kumara et al., 2013), sehingga seleksi 
inbrida berdasarkan penampilannya sendiri juga akan efektif untuk meningkatkan penampilan persilangan yang dihasilkan (Chahal dan Gosal, 2006).

Tabel 2. Nilai kuadrat tengah karakteristik dari 64 genotipe jagung manis keturunan persilangan dialel pada sistem budidaya organik

\begin{tabular}{lrcccccc}
\hline & & \multicolumn{6}{c}{ Kuadrat Tengah } \\
\cline { 3 - 8 } $\begin{array}{c}\text { Sumber } \\
\text { Keragaman }\end{array}$ & $\begin{array}{c}\text { Derajat } \\
\text { Bebas }\end{array}$ & $\begin{array}{c}\text { Panjang } \\
\text { Tongkol }\end{array}$ & $\begin{array}{c}\text { Diameter } \\
\text { Tongkol } \\
\text { Berkelobot }\end{array}$ & $\begin{array}{c}\text { Diameter } \\
\text { Tongkol } \\
\text { Tanpa } \\
\text { Kelobot }\end{array}$ & $\begin{array}{c}\text { Jumlah } \\
\text { Baris } \\
\text { Biji per } \\
\text { Tongkol }\end{array}$ & $\begin{array}{c}\text { Jumlah } \\
\text { Biji per } \\
\text { Baris }\end{array}$ & $\begin{array}{c}\text { Bobot } \\
\text { Tongkol } \\
\text { Berkelobot }\end{array}$ \\
\hline Blok & 2 & $125.09^{* *}$ & $1.36^{* *}$ & $0.82^{* *}$ & 0.26 & $130.93^{* *}$ & $13601.92^{* *}$ \\
Genotipe & 63 & $3.68^{*}$ & $0.17^{* *}$ & $0.14^{* *}$ & $1.90^{* *}$ & 14.29 & $3003.42^{* *}$ \\
Galat & 126 & 2.6 & 0.1 & 0.06 & 0.71 & 13.04 & 1556.18 \\
\hline KK $(\%)$ & & 11.01 & 8.22 & 9.08 & 10.34 & 9.98 & 19.23 \\
\hline
\end{tabular}

Keterangan: $*=\mathrm{P}<0.05$, dan $* *=\mathrm{P}<0.01$

Tabel 3. Nilai rata-rata penampilan karakteristik tongkol dari 64 genotipe jagung manis keturunan persilangan dialel pada sistem budidaya organik

\begin{tabular}{lccccc}
\hline Genotipe & $\begin{array}{c}\text { Panjang } \\
\text { Tongkol } \\
(\mathrm{cm})\end{array}$ & $\begin{array}{c}\text { Diameter } \\
\text { Tongkol } \\
\text { Berkelobot } \\
(\mathrm{cm})\end{array}$ & $\begin{array}{c}\text { Diameter } \\
\text { Tongkol } \\
\text { Tanpa } \\
\text { Kelobot } \\
(\mathrm{cm})\end{array}$ & $\begin{array}{c}\text { Jumlah } \\
\text { Baris Per } \\
\text { Tongkol }\end{array}$ & $\begin{array}{c}\text { Bobot } \\
\text { Tongkol } \\
\text { Berkelobot } \\
(\mathrm{g})\end{array}$ \\
\hline Caps 2 & 17.25 & 5.66 & 4.25 & 13.42 & 214.25 \\
Caps 3 & 16.53 & 6.04 & 4.91 & 15.48 & 267.67 \\
Caps 5 & 20.80 & 5.85 & 4.58 & 14.00 & 298.00 \\
Caps 15 & 18.72 & 5.79 & 4.87 & 15.33 & 264.60 \\
Caps 17A & 20.20 & 6.16 & 4.85 & 15.13 & 318.27 \\
Caps 17B & 20.80 & 5.81 & 5.09 & 15.47 & 319.13 \\
Caps 22 & 19.27 & 5.72 & 5.30 & 14.07 & 314.60 \\
Caps 23 & 17.25 & 5.66 & 4.25 & 13.42 & 214.25 \\
Caps 2 x Caps 3 & 21.13 & 6.24 & 5.27 & 14.40 & 347.67 \\
Caps 2 x Caps 5 & 18.80 & 6.10 & 4.98 & 13.00 & 310.07 \\
Caps 2 x Caps 15 & 18.80 & 5.96 & 4.55 & 13.80 & 281.80 \\
Caps 2 x Caps 17A & 20.47 & 6.19 & 4.98 & 14.07 & 331.00 \\
Caps 2 x Caps 17B & 19.60 & 5.67 & 4.87 & 15.13 & 288.07 \\
Caps 2 x Caps 22 & 19.13 & 5.59 & 4.69 & 13.33 & 270.47 \\
Caps 2 x Caps 23 & 19.47 & 5.55 & 4.73 & 13.07 & 269.80 \\
Caps 3 x Caps 5 & 20.87 & 5.90 & 5.39 & 14.87 & 349.00 \\
Caps 3 x Caps 15 & 18.87 & 6.16 & 5.21 & 14.53 & 334.80 \\
Caps 3 x Caps 17A & 20.93 & 6.22 & 5.02 & 14.80 & 363.00 \\
Caps 3 x Caps 17B & 19.80 & 6.20 & 5.49 & 14.52 & 338.27 \\
Caps 3 x Caps 22 & 18.20 & 5.54 & 4.96 & 13.60 & 280.93 \\
Caps 3 x Caps 23 & 20.33 & 5.98 & 5.14 & 14.40 & 359.93 \\
Caps 5 x Caps 15 & 21.42 & 6.16 & 4.98 & 14.27 & 326.00 \\
\hline
\end{tabular}




\begin{tabular}{|c|c|c|c|c|c|}
\hline $\begin{array}{r}\text { Lanjutan Tabel 3. Nila } \\
\text { ketu }\end{array}$ & $\begin{array}{l}\text {-rata pe } \\
\text { persila }\end{array}$ & $\begin{array}{l}\text { kara } \\
\text { el pad }\end{array}$ & $\begin{array}{l}\text { ngko } \\
\text { udida }\end{array}$ & genot & ing man \\
\hline Caps 5 x Caps 17A & 20.80 & 6.13 & 5.26 & 14.53 & 351.80 \\
\hline Caps 5 x Caps 17B & 19.27 & 6.15 & 5.33 & 16.27 & 345.13 \\
\hline Caps 5 x Caps 22 & 19.53 & 6.19 & 5.13 & 14.73 & 328.00 \\
\hline Caps 5 x Caps 23 & 20.00 & 5.82 & 4.92 & 13.90 & 295.93 \\
\hline Caps 15 x Caps 17A & 19.20 & 5.86 & 5.12 & 15.33 & 292.73 \\
\hline Caps 15 x Caps 17B & 17.73 & 6.05 & 5.05 & 16.33 & 288.40 \\
\hline Caps 15 x Caps 22 & 17.80 & 5.97 & 5.13 & 15.73 & 294.87 \\
\hline Caps 15 x Caps 23 & 19.27 & 5.73 & 4.88 & 14.40 & 308.53 \\
\hline Caps 17A x Caps 17B & 19.80 & 6.24 & 4.96 & 15.67 & 366.33 \\
\hline Caps 17A x Caps 22 & 19.20 & 5.94 & 4.94 & 14.60 & 307.00 \\
\hline Caps 17A x Caps 23 & 19.80 & 6.04 & 5.21 & 14.80 & 325.87 \\
\hline Caps 17B x Caps 22 & 18.20 & 6.16 & 5.01 & 14.67 & 314.20 \\
\hline Caps 17B x Caps 23 & 19.27 & 5.85 & 4.92 & 14.80 & 310.20 \\
\hline Caps 22 x Caps 23 & 17.40 & 5.97 & 4.85 & 14.52 & 305.80 \\
\hline Caps 3 x Caps 2 & 20.67 & 5.99 & 5.01 & 14.12 & 345.27 \\
\hline Caps 5 x Caps 2 & 18.53 & 6.07 & 4.85 & 12.73 & 298.07 \\
\hline Caps 15 x Caps 2 & 19.87 & 6.25 & 5.07 & 14.60 & 332.47 \\
\hline Caps 17A x Caps 2 & 19.33 & 6.29 & 5.32 & 14.40 & 358.13 \\
\hline Caps 17B x Caps 2 & 20.07 & 6.04 & 4.93 & 13.60 & 317.93 \\
\hline Caps 22 x Caps 2 & 19.78 & 6.22 & 5.16 & 14.85 & 334.30 \\
\hline Caps 23 x Caps 2 & 18.87 & 5.87 & 4.83 & 14.40 & 297.33 \\
\hline Caps 5 x Caps 3 & 20.60 & 6.14 & 5.24 & 14.07 & 332.13 \\
\hline Caps 15 x Caps 3 & 20.80 & 6.31 & 5.16 & 15.13 & 350.07 \\
\hline Caps 17A x Caps 3 & 20.80 & 6.14 & 5.38 & 14.93 & 356.60 \\
\hline Caps 17B x Caps 3 & 20.32 & 5.77 & 5.07 & 14.03 & 313.30 \\
\hline Caps 22 x Caps 3 & 17.67 & 5.67 & 4.98 & 14.73 & 274.00 \\
\hline Caps $23 \times$ Caps 3 & 18.00 & 5.83 & 4.78 & 14.53 & 295.07 \\
\hline Caps 15 x Caps 5 & 19.33 & 6.01 & 4.90 & 14.73 & 295.67 \\
\hline Caps 17A x Caps 5 & 21.33 & 6.62 & 5.43 & 14.93 & 393.60 \\
\hline Caps 17B x Caps 5 & 20.27 & 6.11 & 5.20 & 14.87 & 339.73 \\
\hline Caps 22 x Caps 5 & 18.47 & 5.85 & 5.12 & 14.77 & 303.93 \\
\hline Caps $23 \times$ Caps 5 & 21.20 & 6.06 & 5.08 & 14.00 & 332.27 \\
\hline Caps 17 A x Caps 15 & 21.40 & 6.61 & 5.15 & 16.20 & 370.00 \\
\hline Caps 17B x Caps 15 & 19.53 & 6.27 & 5.13 & 16.20 & 346.33 \\
\hline Caps 22 x Caps 15 & 19.93 & 6.10 & 5.08 & 15.73 & 336.67 \\
\hline Caps 23 x Caps 15 & 21.00 & 5.99 & 5.03 & 14.93 & 336.67 \\
\hline Caps 17B x Caps 17A & 21.40 & 5.67 & 5.15 & 15.80 & 319.20 \\
\hline Caps 22 x Caps 17A & 18.73 & 5.63 & 4.92 & 14.93 & 275.00 \\
\hline Caps $23 \times$ Caps $17 \mathrm{~A}$ & 18.40 & 6.45 & 5.15 & 14.60 & 358.00 \\
\hline Caps $22 \times$ Caps 17B & 19.80 & 6.09 & 5.16 & 15.47 & 317.40 \\
\hline Caps $23 \times$ Caps 17B & 18.73 & 5.67 & 5.10 & 15.47 & 300.60 \\
\hline Caps 23 x Caps 22 & 19.93 & 6.11 & 5.30 & 15.33 & 321.40 \\
\hline BNT 5\% & 1.84 & 0.36 & 0.28 & 4.13 & 45.10 \\
\hline
\end{tabular}




\section{Daya Gabung}

Dalam analisis ragam, jumlah biji per baris tidak menunjukkan perbedaan yang nyata antar genotipe sehingga tindak gen yang mengendalikan ekspresi karakter tersebut tidak dapat diidentifikasi. Karena itu, penguraian keragaman genotipe menjadi pengaruh daya gabung umum (DGU), daya gabung khusus (DGK), dan resiprokal hanya dilakukan terhadap lima karakter yang secara genotipik beragam (Shattuck et al., 1993; Roy, 2000) dan hasilnya disajikan pada Tabel 4. DGU memiliki kontribusi relatif besar terhadap keragaman genotipe dengan kisaran dari $42 \%$ sampai $78 \%$ dan berpengaruh sangat nyata pada kelima karakter tersebut, sedangkan DGK memiliki kontribusi terhadap keragaman genotipe dengan kisaran dari 10\% sampai 36\% dan berpengaruh tidak nyata hanya pada panjang tongkol. Kontribusi pengaruh resiprokal terhadap keragaman ganotipe umumnya relatif kecil dan hanya nyata pada diameter tongkol tanpa kelobot.

DGU merupakan indikator potensi inbrida sebagai penggabung ketika disilangkan dengan inbrida lainnya. Pada jagung manis, karakteristik tongkol menjadi pertimbangan sama pentingnya dengan hasil. Karena itu, inbrida yang memiliki pengaruh DGU tinggi dan positif terhadap karakteristik tongkol dan hasil menjadi rujukan dalam menentukan inbrida sebagai tetua dalam perakitan varietas hibrida atau sintetis. Dari 8 inbrida yang dievaluasi, Caps 17A merupakan penggabung terbaik karena memiliki DGU yang sedang dan tinggi pada sebagian besar (Tabel 5). Caps 17B merupakan penggabung yang baik untuk jumlah baris biji per tongkol. Caps 5 merupakan penggabung yang baik untuk panjang tongkol. Secara teoritis, pengaruh DGU merupakan manifestasi tindak gen aditif (Sprague dan Tatum, 1942) dan berdasarkan nisbah kuadrat tengah DGU/DGK (Tabel 3), seluruh karakter memiliki nilai > 1.00 sehingga dapat diartikan bahwa tindak gen aditif memiliki peran utama dalam mengendalikan pewarisan karakter-karakter tersebut. Peran tindak gen aditif yang lebih besar dibanding tindak gen non-aditif sudah umum dijumpai pada jagung manis (Zare et al., 2011; Srdić et al., 2011). Secara praktis, karakter-karakter yang dikendalikan tindak gen aditif dapat difiksasi dan diakumulasi melalui seleksi dan inbreeding pada generasi berikutnya (Reddy dan Patil, 2015).

Tabel 4. Nilai kuadrat tengah dan persentase kuadrat tengah (dalam kurung) daya gabung karakteristik tongkol dari 64 genotipe jagung manis keturunan persilangan dialel pada sistem budidaya organik

\begin{tabular}{|c|c|c|c|c|c|c|}
\hline \multirow[b]{2}{*}{$\begin{array}{l}\text { Sumber } \\
\text { Keragaman }\end{array}$} & \multirow[b]{2}{*}{$\begin{array}{c}\text { Derajat } \\
\text { Bebas }\end{array}$} & \multicolumn{5}{|c|}{ Kuadrat Tengah (KT) } \\
\hline & & $\begin{array}{l}\text { Panjang } \\
\text { Tongkol }\end{array}$ & $\begin{array}{c}\text { Diameter } \\
\text { Tongkol } \\
\text { Berkelobot }\end{array}$ & $\begin{array}{c}\text { Diameter } \\
\text { Tongkol } \\
\text { Tanpa } \\
\text { Kelobot }\end{array}$ & $\begin{array}{c}\text { Jumlah Baris } \\
\text { Per Tongkol }\end{array}$ & $\begin{array}{c}\text { Bobot } \\
\text { Tongkol } \\
\text { Berkelobot }\end{array}$ \\
\hline DGU & 7 & $\begin{array}{l}2.86^{* *} \\
(49 \%)\end{array}$ & $\begin{array}{l}0.10 * * \\
(42 \%)\end{array}$ & $\begin{array}{l}0.11 * * \\
(52 \%)\end{array}$ & $\begin{array}{l}3.11 * * \\
(78 \%)\end{array}$ & $\begin{array}{l}2212.03^{* *} \\
(50 \%)\end{array}$ \\
\hline DGK & 28 & $\begin{array}{l}1.26 \\
(22 \%)\end{array}$ & $\begin{array}{l}0.06^{*} \\
(25 \%)\end{array}$ & $\begin{array}{l}0.05^{* *} \\
(24 \%)\end{array}$ & $\begin{array}{l}0.38^{*} \\
(10 \%)\end{array}$ & $\begin{array}{l}1062.05^{* * *} \\
(24 \%)\end{array}$ \\
\hline Resiprokal & 28 & $\begin{array}{l}0.79 \\
(14 \%)\end{array}$ & $\begin{array}{l}0.05 \\
(21 \%)\end{array}$ & $\begin{array}{l}0.03^{*} \\
(14 \%)\end{array}$ & $\begin{array}{l}0.27 \\
(7 \%)\end{array}$ & $\begin{array}{l}637.51 \\
(14 \%)\end{array}$ \\
\hline Galat & 126 & $\begin{array}{l}0.87 \\
(15 \%) \\
\end{array}$ & $\begin{array}{l}0.03 \\
(13 \%) \\
\end{array}$ & $\begin{array}{l}0.02 \\
(10 \%) \\
\end{array}$ & $\begin{array}{l}0.24 \\
(6 \%) \\
\end{array}$ & $\begin{array}{l}518.73 \\
(12 \%) \\
\end{array}$ \\
\hline DGU /DGK & & 2.27 & 1.67 & 2.2 & 8.18 & 2.08 \\
\hline
\end{tabular}


Tabel 5. Nilai daya gabung umum (DGU) karakteristik tongkol dari 8 galur inbrida jagung manis dari persilangan dialel pada sistem budidaya organik

\begin{tabular}{lccccc}
\hline Inbrida & $\begin{array}{c}\text { Panjang } \\
\text { Tongkol }\end{array}$ & $\begin{array}{c}\text { Diameter } \\
\text { Tongkol } \\
\text { Berkelobot }\end{array}$ & $\begin{array}{c}\text { Diameter } \\
\text { Tongkol } \\
\text { Tanpa } \\
\text { Kelobot }\end{array}$ & $\begin{array}{c}\text { Jumlah } \\
\text { Baris Per } \\
\text { Tongkol }\end{array}$ & $\begin{array}{c}\text { Bobot } \\
\text { Tongkol } \\
\text { Berkelobot }\end{array}$ \\
\hline Caps 2 & -0.25 & -0.05 & $-0.18^{* *}$ & $-0.80^{* *}$ & $-16.97^{* *}$ \\
Caps 3 & -0.06 & 0.00 & $0.08^{*}$ & -0.10 & 5.81 \\
Caps 5 & $0.57^{*}$ & 0.05 & 0.02 & $-0.34^{* *}$ & 7.19 \\
Caps 15 & -0.04 & 0.05 & -0.03 & $0.46^{* *}$ & -3.63 \\
Caps 17A & $0.57^{*}$ & $0.14^{* *}$ & $0.07^{*}$ & $0.29^{*}$ & $20.15^{* *}$ \\
Caps 17B & 0.15 & -0.04 & 0.06 & $0.54^{* *}$ & 3.81 \\
Caps 22 & $-0.66^{* *}$ & -0.11 & 0.02 & 0.00 & $-11.82^{*}$ \\
Caps 23 & -0.28 & -0.05 & -0.03 & -0.04 & -4.55 \\
\hline
\end{tabular}

Keterangan: $*=\mathrm{P}<0.05$, dan $* *=\mathrm{P}<0.01$

Pada Tabel 6 disajikan taksiran pengaruh DGK. Di antara hibrida yang dievaluasi, Caps 2 x Caps 3 merupakan kombinasi persilangan terbaik karena menghasilkan DGK positif untuk tujuh karakter dan empat diantaranya memiliki nilai sedang hingga tinggi. Pada Tabel 7 disajikan kombinasi persilangan yang menempati urutan atas DGK pada masing-masing karakter berikut nilai DGU tetua penyusunnya. Secara umum, besarnya nilai DGK tampaknya tidak terkait langsung dengan nilai DGU inbrida penyusunnya, sehingga kombinasi inbrida yang memiliki DGU tinggi dan searah akan menghasilkan DGK tinggi (Paul dan Duara, 1991) tidak dijumpai dalam evaluasi ini.
Hibrida yang memiliki DGK tinggi dan positif dapat tersusun dari kombinasi inbrida dengan DGU tinggi, sedang atau rendah dengan arah positif maupun negatif. Fenomena serupa pada jagung manis juga dilaporkan oleh Worrajinda et al. (2013) dan Rifianto et al. (2014). Pengaruh DGK yang tinggi menunjukkan bahwa tindak gen non-aditif juga ikut berperan dalam ekspresi karakter (Sprague dan Tatum, 1942) dan arah DGK menunjukkan arah simpangan gen dominan (Viana, 2000). Berbeda dengan tindak gen aditif, tindak gen non-aditif tidak dapat difiksasi melalui seleksi atau inbreeding, melainkan harus dimanfaatkan pada kondisi lingkungan yang menguntungkan heterosigot.

Table 6. Nilai daya gabung khusus (DGK) karakteristik tongkol dari 28 kombinasi persilangan dialel pada sistem budidaya organik

\begin{tabular}{lccccc}
\hline Hibrida & $\begin{array}{c}\text { Panjang } \\
\text { Tongkol }\end{array}$ & $\begin{array}{c}\text { Diameter } \\
\text { Tongkol } \\
\text { Berkelobot }\end{array}$ & $\begin{array}{c}\text { Diameter } \\
\text { Tongkol Tanpa } \\
\text { Kelobot }\end{array}$ & $\begin{array}{c}\text { Jumlah Baris } \\
\text { Biji Per } \\
\text { Tongkol }\end{array}$ & $\begin{array}{c}\text { Bobot } \\
\text { Tongkol } \\
\text { Berkelobot }\end{array}$ \\
\hline Caps 2 x Caps 3 & $1.64^{* *}$ & 0.16 & $0.20^{*}$ & 0.46 & $39.97^{* *}$ \\
Caps 2 x Caps 5 & $-1.21^{*}$ & 0.08 & 0.04 & $-0.68^{*}$ & -3.80 \\
Caps 2 x Caps 15 & 0.06 & 0.09 & -0.02 & -0.16 & 10.09 \\
Caps 2 x Caps 17A & 0.02 & 0.14 & $0.23^{*}$ & 0.05 & 23.73 \\
Caps 2 x Caps 17B & 0.37 & -0.07 & -0.02 & -0.07 & -1.49 \\
Caps 2 x Caps 22 & 0.81 & 0.05 & 0.04 & 0.20 & 13.53 \\
Caps 2 x Caps 23 & 0.13 & -0.20 & -0.05 & -0.12 & -12.56 \\
Caps 3 x Caps 5 & 0.66 & -0.05 & 0.17 & 0.21 & 9.92 \\
Caps 3 x Caps 15 & 0.37 & 0.17 & 0.09 & -0.23 & 22.61 \\
Caps 3 x Caps 17A & 0.80 & 0.03 & 0.02 & -0.03 & 16.19 \\
Caps 3 x Caps 17B & 0.40 & 0.01 & 0.11 & $-0.86^{* *}$ & -1.49 \\
\hline
\end{tabular}




\begin{tabular}{lccccc}
\hline Lanjutan Table 6. Nilai daya gabung khusus (DGK) & karakteristik & tongkol dari & 28 & kombinasi \\
\multicolumn{7}{c}{ persilangan dialel pada sistem budidaya organik } \\
\hline Caps 3 x Caps 22 & -0.91 & $-0.30^{*}$ & -0.18 & -0.43 & $-34.17^{*}$ \\
Caps 3 x Caps 23 & -0.06 & -0.06 & -0.12 & -0.09 & 8.59 \\
Caps 5 x Caps 15 & 0.29 & -0.03 & -0.09 & -0.32 & -10.37 \\
Caps 5 x Caps 17A & 0.38 & 0.18 & $0.22^{*}$ & 0.09 & 27.71 \\
Caps 5 x Caps 17B & -0.51 & 0.11 & 0.15 & $0.68^{*}$ & 13.79 \\
Caps 5 x Caps 22 & -0.46 & 0.06 & 0.04 & 0.40 & 2.96 \\
Caps 5 x Caps 23 & 0.75 & -0.08 & -0.03 & -0.36 & -6.18 \\
Caps 15 x Caps 17A & 0.21 & 0.03 & 0.05 & 0.31 & 2.80 \\
Caps 15 x Caps 17B & -1.04 & 0.13 & 0.02 & 0.57 & -0.46 \\
Caps 15 x Caps 22 & 0.01 & 0.08 & 0.07 & 0.57 & 13.58 \\
Caps 15 x Caps 23 & 0.89 & -0.15 & -0.02 & -0.45 & 13.14 \\
Caps 17A x Caps 17B & 0.32 & -0.16 & -0.11 & 0.21 & 1.15 \\
Caps 17A x Caps 22 & -0.49 & $-0.26^{*}$ & -0.20 & -0.22 & $-34.98^{*}$ \\
Caps 17A x Caps 23 & -0.75 & 0.15 & 0.11 & -0.25 & 8.68 \\
Caps 17B x Caps 22 & -0.05 & $0.26^{*}$ & -0.04 & 0.21 & 6.16 \\
Caps 17B x Caps 23 & -0.43 & -0.17 & -0.05 & 0.21 & -11.51 \\
Caps 22 x Caps 23 & 0.05 & 0.19 & 0.05 & -0.22 & 12.33 \\
\hline
\end{tabular}

Keterangan: * $\mathrm{P}<0.05$, dan $* *=\mathrm{P}<0.01$

Tabel 7. Hibrida dengan DGK peringkat atas untuk tiap karakter tongkol berikut DGU inbrida penyusunnya

\begin{tabular}{llrl}
\hline Karakter & \multicolumn{1}{c}{ Kombinasi } & DGK & \multicolumn{1}{c}{ DGU } \\
\hline Panjang Tongkol & Caps 2 x Caps 3 & 1.64 & rendah negatif x rendah negatif \\
Diameter Tongkol Berkelobot & Caps 17B x Caps 22 & 0.26 & rendah negatif x rendah negatif \\
Diameter Tongkol Tanpa kelobot & Caps 2 x Caps 17A & 0.23 & tinggi negatif x sedang positif \\
& Caps 5 x Caps 17 A & 0.22 & rendah positif x sedang positif \\
& Caps 2 x Caps 3 & 0.20 & tinggi negatif x sedang positif \\
Jumlah Baris Biji per Tongkol & Caps 5 x Caps 17B & 0.68 & tinggi negatif x sedang positif \\
Bobot Tongkol Berkelobot & Caps 2 x Caps 3 & 39.97 & tinggi negatif x rendah positif \\
\hline
\end{tabular}

Pengaruh resiprokal yang dijumpai pada diameter tongkol tanpa kelobot dapat terjadi karena faktor pewarisan maternal, faktor pewarisan sitoplasma, atau interaksi genom plasma (Ram, 2014). Namun demikian, pemisahan dan penentuan besarnya peran dari masing-masing faktor tersebut tidak dapat dilakukan berdasarkan data yang diperoleh dari penelitian ini.

\section{KESIMPULAN}

Berdasarkan analisis ragam, perbedaan genotipe berperan penting terhadap keragaman panjang tongkol, diameter tongkol berkelobot, diameter tongkol tanpa kelobot, jumlah biji per baris, dan bobot tongkol berkelobot di antara delapan galur inbrida jagung manis pada sistem budidaya organik. Evaluasi terhadap daya gabung umum (DGU) menunjukkan bahwa beberapa inbrida memiliki potensi yang besar sebagai calon tetua untuk perakitan varietas hibrida maupun varietas sintetis. Caps 17A merupakan penggabung yang baik untuk meningkatkan panjang tongkol, diameter tongkol berkelobot, diameter tongkol tanpa kelobot, jumlah baris biji per tongkol, dan bobot tongkol berkelobot. Caps 17B merupakan penggabung yang baik untuk meningkatkan jumlah baris biji per tongkol. Caps 5 merupakan penggabung yang baik untuk meningkatkan panjang tongkol. Caps 2 $\mathrm{x}$ Caps 3 merupakan kombinasi persilangan 
terbaik dengan menghasilkan daya gabung khusus (DGK) yang tinggi dan positif untuk panjang tongkol, diameter tongkol tanpa kelobot, jumlah baris biji per tongkol, dan bobot tongkol berkelobot. Namun demikian, nilai DGK tersebut belum banyak memberi manfaat dalam program karena pada tahap ini fokus seleksi masih diarahkan untuk pengembangan galur inbrida. Di waktu mendatang, kajian daya gabung perlu dilakukan pada kondisi lingkungan organik yang berbeda guna mengevaluasi konsistensi DGU maupun DGK lintas lingkungan agar kombinasi persilangan yang unggul dan adaptif pada sistem budidaya organik dapat diidentifikasi.

\section{UCAPAN TERIMA KASIH}

Kami mengucapkan terima kasih kepada Direktorat Jenderal Pendidikan Tinggi Kementerian Riset Teknologi Pendidikan Tinggi yang telah mendanai pelaksanaan penelitian kami melalui skim Penelitian Hibah Bersaing Tahun 2015. Ucapan terima kasih juga kami sampaikan kepada Oktavia Rahmayanti, S.P. yang telah membantu pelaksanaan penelitian kami.

\section{DAFTAR PUSTAKA}

Acquaah, G. 2012. Principles of Plant Genetics and Breeding, $2^{\text {nd }}$ ed. John Wiley dan Sons. West Sussex. UK.

Agustyari, N.K., I. Antara, I.G.A.A.L. Anggreni. 2013. Perbandingan pendapatan usahatani jagung manis dan padi di Subak Delod Sema Padanggalak Desa Kesiman Petilan, Kecamatan Denpasar Timur. E-Journal Agribisnis dan Agrowisata. 2(4): 224-235.

Assunção, A., E.M. Brasil, J.P.D. Oliveira, A J.D.S. Reis, A.F. Pereira, L.G. Bueno, M.R. Ramos. 2010. Heterosis Performance in industrial and yield components of sweet corn. Crop Breeding and Applied Biotechnology. 10(3): 183-190.
Chahal, G.S., S.S. Gosal. 2006. Principles and Procedures of Plant Breeding. Biotechnological, and Conventional Approaches. Alpha Sci. International Ltd. Harrow. UK.

Dinariani, D., Y.B. Heddy, Guritno. 2014. Kajian penambahan pupuk kandang kambing dan kerapatan tanaman yang berbeda pada pertumbuhan dan hasil tanaman jagung manis (Zea mays saccharata Sturt). J. Prod. Tan. 2(2): 128-139.

Direktorat Jenderal Hortikultura. 2013. Volume impor dan ekspor sayuran tahun 2012. Direktorat Jenderal Hortikultura, Kementerian Pertanian RI. http://hortikultura.pertanian.go.id/index. php?view $=$ article $\&$ catid $=57 \% 3$ Aekspor -impor\&id=337\%3 Avolume-impor-aekspor-sayuran-th2012\&format=pdf\& option=com_content $\&$ Itemid $=698$. [02 Juni 2014].

Ekowahyuni, L.P., M. Syukur, S.H. Sutjahjo, M.R Suhartanto. 2015. Pendugaan parameter genetik vigor untuk viabilitas dan vigor benih cabai (Capsicum annuum L.) menggunakan analisis setengah dialel. J. Hort. Indonesia. 6(3): 144-151.

Fahrurrozi, Z. Muktamar, N. Setyowati, S Sudjatmiko, M. Chozin. 2016. Growth and yield responses of three sweet corn (Zea mays var. saccharata) varieties to local-based liquid organic fertilizer. International Journal on Advanced Science. Engineering and Information Technology. 6(3): 319-323.

Griffing, B. 1956. Concept of general and specific combining ability in relation to diallel crossing systems. Australian J. Biological Sciences. 9(4): 463-493.

Iriany, R.N., S. Sujiprihati, M. Syukur, J. Koswara, M. Yunus. 2011. Evaluasi daya gabung dan heterosis lima galur jagung manis (Zea mays var. saccharata) hasil persilangan dialel. J. Agron. Indonesia. 39(2): 103-111. 
Koswara, J. 1986. Budidaya jagung manis (Zea mays var. saccharata) Bahan kursus budidaya jagung manis dan jagung merang. Fakultas Pertanian. IPB, Bogor.

Kumara, B.S., K.N. Ganesan, G. Nallathambi, N. Senthil. 2013. Heterosis of single cross sweet corn hybrids developed with inbreds of domestic genepool. Madras Agricultural Journal. 100(1/3): 52-56.

Marvelita, A., S. Darmanti, S. Parman. 2006. Produksi tanaman jagung manis (Zea mays var. saccharata) yang diperlakukan dengan kompos kascing dengan dosis yang berbeda. Buletin Anatomi dan Fisiologi. 14(2): 7-18.

Mayadewi, A., N. Nyoman. 2007. Pengaruh jenis pupuk kandang dan jarak tanam terhadap pertumbuhan gulma dan hasil jagung manis. Agritrop. 26(4): 153-159.

Muhsanati, A.S., S. Rahayu. 2008. Pengaruh beberapa takaran kompos tithonia terhadap pertumbuhan dan hasil tanaman jagung manis (Zea mays var. saccharata). Jerami. 1(2): 87-91.

Muktamar, Z., N. Setyowati, S. Sudjatmiko, M. Chozin. 2016. Selected macronutrient uptake by sweet corn under different rates of liquid organic fertilizer in closed agriculture system. International Journal on Advanced Science, Engineering and Information Technology. 6(2): 258261.

Nurkhasanah, N. 2012. Pengendalian hama penggerek tongkol jagung Helicoverpa armigera Hubner. (Lepidoptera: Noctuidae) dengan Beauveria bassiana strain lokal pada pertanaman jagung manis di Kabupaten Donggala. Agroland. 15(2): 106-111.

Ompusunggu, D.S., S. Oemry, L. Lubis. 2015. Uji efektivitas jamur Metarhizium anisopliae (Metch.) dan Helicoverpa armigera Nuclear Polyhedrosis Virus (HaNPV) terhadap larva penggerek tongkol jagung Helicoperva armigera
Hubner (Lepidoptera: Noctuidae) di Lapangan. J. Agroekoteknologi. 3(2): 779-784.

Paul, S.K., P.K Duara. 1991. Combining ability studies in maize (Zea mays L.). Intl. J. Trop. Agriculture. 9(4): 245-249.

Poehlman, J.M. 2013. Breeding Field Crops. $3^{\text {rd }}$ Edition. Springer Science \& Business Media. New York.

Porotu'o, L.C., C. Talumingan, E.G. Tangkere, M.L. Taroreh. 2013. Analisis pendapatan usaha tani jagung manis aminduk di kebun showindows Desa Kembuan, Kecamatan Tondano Utara. Cocos. 2(2): 1-35.

Rahmah, A., M. Izzati, S. Parman. 2014. Pengaruh pupuk organik cair berbahan dasar limbah sawi putih (Brassica chinensis L.) terhadap pertumbuhan tanaman jagung manis. Buletin Anatomi dan Fisiologi. 22(1): 65-71.

Ram, M. 2014. Plant Breeding Methods. PHI Learning Private Ltd., Delhi.

Reddy, S., J.V. Patil. 2015. Genetic Enhancement of Rabi Sorghum: Adapting the Indian Durras. Academic Press.

Rifianto, A., M. Syukur, Trikoesoemaningtyas, Widodo. 2014. Daya gabung hasil dan komponen hasil tujuh galur jagung manis di dua lokasi. J. Agron. Indonesia. 41(3): 235-241.

Roy, D. 2000. Plant Breeding: Analysis and Exploitation of Variation. Alpha Science International, Harrow. U.K.

Sadaiah, K., V.N. Reddy, S.S. Kumar. 2013. Heterosis and combining ability studies for sugar content in sweet corn (Zea mays saccharata L.). International Journal of Scientific and Research Publications. 3(3): 1-5.

Sekarsari, R.A., J. Prasetyo, T. Maryono. 2013. Pengaruh beberapa fungisida nabati terhadap keterjadian penyakit 
bulai pada jagung manis (Zea mays saccharata). J. Agrotek Tropika. 1(1): 98-101.

Shattuck, V.I., B. Christie, C. Corso. 1993. Principles for Griffing's combining ability analysis. Genetica. 90(1): 73-77.

Singh, R.K., B.D. Chaudhary. 1985. Biometrical Methods in Quantitative Genetics Analysis. Kalyani Publishers, New Delhi-Ludhiana.

Silmi, F., M.A. Chozin,. 2014. Pemanfaatan biomulsa kacang hias (Arachis pintoi) pada budidaya jagung manis (Zea mays saccharata Sturt.) di lahan kering. J. Hort. Indonesia. 5(1): 1-9

Solomon, K.F., A. Zeppa, S.D. Mulugeta. 2012. Combining ability, genetic diversity and heterosis in relation to $\mathrm{F} 1$ performance of tropically adapted shrunken (sh2) sweet corn lines. Plant Breeding. 131(3): 430-436.

Sprague, G. F., L.A. Tatum. 1942. General vs. specific combining ability in single crosses of corn. Agronomy Journal. 34(10): 923-932.

Srdić, J., Z. Pajić, M. Filipović, M. Babić, M. Sečanski. 2011. Inheritance of ear yield and its components in sweet corn (Zea mays L. saccharata). Genetika. 43(2): 341-348.

Susianti, N., R.A. Rauf. 2013. Analisis faktorfaktor yang mempengaruhi pendapatan usahatani jagung manis (Studi Kasus: di Desa Sidera Kecamatan Sigi Biromaru Kabupaten Sigi). Agrotekbis. 1(5): 500508.
Syaiful, S.A., A. Yassi, N. Rezkiani. 2011 Respon tumpangsari tanaman jagung manis dan kacang hijau terhadap sistem olah tanah dan pemberian pupuk organik. J. Fakultas Pertanian. 1(1): 1318.

Viana, J.M.S. 2000. The parametric restrictions of the Griffing diallel analysis model: combining ability analysis. Genetics and Molecular Biology. 23(4): 877-881.

Welu, G. 2016. Development and applications of synthetic varieties in crop improvement. Int. J. Eng. Development and Research. 4(2): 424-429.

Wolfe, M.S. 2003. Plant breeding, ecology and modern organic agriculture. In: E.T. Lammerts van Bueren and K-P. Wilbois (Eds.) Organic Seed Production and Plant Breeding-Strategies, Problems and Perspectives. Proceedings of ECO$\mathrm{PB} 1^{\text {st }}$ International Symposium on Organic Seed Production and Plant Breeding, Berlin, Germany, 21-22 November 2002, (pp. 18-24). European Consortium of Organic Plant Breeding (ECO-PB), Driebergen/Frankfurt.

Worrajinda, J., K. Lertrat, B. Suriharn. 2013. Combining ability of super sweet corn inbred lines with different ear sizes for ear number and whole ear weight. Sabrao J. Breed. Genet. 45(3): 468-477.

Zare, M., R. Choukan, E.M. Heravan, M.R. Bihamta, K. Ordookhani. 2011. Geneaction of some agronomic traits in corn (Zea mays L) using diallel cross analysis. African J. Agric. Res. 6(3): 693-703. 